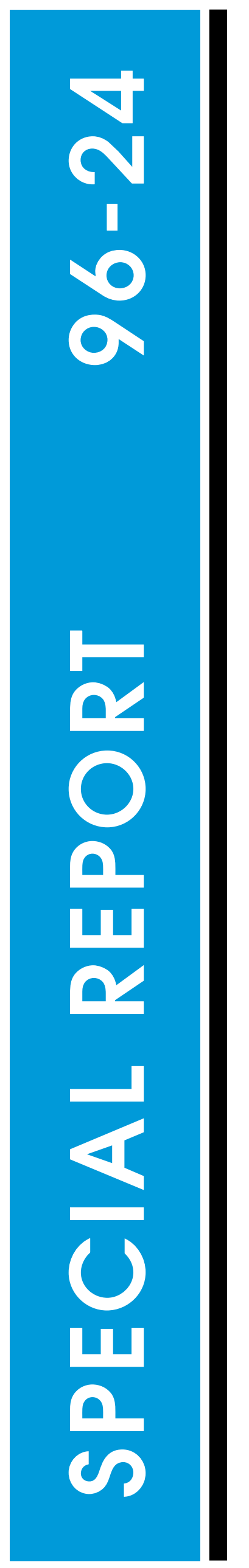

Plant Growth Regulators' Effect on Growth of Mixed Cool-Season Grass Stands at Fort Drum

Antonio J. Palazzo, Paul Zang, Robert W. Duell, Timothy J. Cary and Susan E. Hardy 
Abstract: Mowing is one of the more expensive operations in managing roadside and other low-maintenance turfgrass areas. The objective of this study was to evaluate the performance of two plant growth regulators (PGRs) - mefluidide (Embark) and imidazolinone (Event) - in reducing the development of seedheads and inhibiting the vertical growth (plant height) of mixed turf swards at multiple sites over a two-year period. Mefluidide applied at the manufacturer's recommended rate (2.3 L/ha or 2 pints/acre) provided the best general control of plant height and seedhead development compared to mefluidide at lower rates or imidazolinone at both recommended and lower rates or a combination of mefluidide and imidazolinone at lower rates. Within the control areas (no PGR), plant height did not correlate with plant weight. Therefore, the timing of treatments is critical since increases in plant height and weight occur at different times during the spring. At the early May application time, mefluidide applied at the recommended rate inhibited both plant height and weight. The effects of this treatment on plant growth were similar in most of the eight sites tested. However, PGR performance was affected by the presence of earlier maturing grasses in the sward, microclimatic factors, and broadleaf weeds. There was no difference in the effectiveness of the treatments when the materials were applied again during the following season. Despite some variation in its effect, the mefluidide treatment at the recommended rate was consistent enough among all test locations, turf species, and microclimates to recommend using this technique in the demonstration stage of the trial.

\section{How to get copies of CRREL technical publications:}

Department of Defense personnel and contractors may order reports through the Defense Technical Information Center: DTIC-BR SUITE 0944

8725 JOHN J KINGMAN RD

FT BELVOIR VA 22060-6218

Telephone 18002253842

E-mail help@dtic.mil

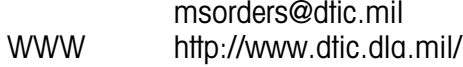

All others may order reports through the National Technical Information Service: NTIS

5285 PORT ROYAL RD

SPRINGFIELD VA 22161

Telephone 17034874650

17034874639 (TDD for the hearing-impaired)

E-mail orders@ntis.fedworld.gov

WWW http://www.fedworld.gov/ntis/ntishome.html

A complete list of all CRREL technical publications is available from: USACRREL (CECRL-TL)

72 LYME RD

HANOVER NH 03755-1290

Telephone 16036464338

E-mail_techpubs@crrel.usace.army.mil

For information on all aspects of the Cold Regions Research and Engineering Laboratory, visit our World Wide Web site: http://www.crrel.usace.army.mil 


\section{Special Report 96-24}

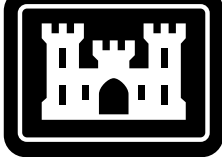

US Army Corps

of Engineers

Cold Regions Research \& Engineering Laboratory

\section{Plant Growth Regulators' Effect on Growth of Mixed Cool-Season Grass Stands at Fort Drum}

Antonio J. Palazzo, Paul Zang, Robert W. Duell, Timothy J. Cary and Susan E. Hardy 


\section{PREFACE}

This report was prepared by Antonio J. Palazzo, Research Agronomist, Geochemical Sciences Division, Research and Engineering Directorate, U.S. Army Cold Regions Research and Engineering Laboratory (CRREL), Hanover, New Hampshire; Paul Zang, Forester, Fort Drum, New York; and by Robert W. Duell, Consultant, Timothy Cary, Physical Science Technician, and Susan E. Hardy, Research Program Specialist, Geochemical Sciences Division, Research and Engineering Directorate, CRREL.

Funding for this work was provided by the Environmental Division, Public Works, at Fort Drum and the U.S. Army Forces Command, Fort McPherson, Georgia.

The authors thank Alan Schwark, Range Control, Ann Johnson and Michelle Tuckley, Public Works Division, Fort Drum, for helping to conduct this study, and Dr. Gurdarshan S. Brar, formerly of CRREL, and William Woodson, U.S. Army Environmental Center, Aberdeen, Maryland, for technical review of this manuscript.

The contents of this report are not to be used for advertising or promotional purposes. Citation of brand names does not constitute an official endorsement or approval of the use of such commercial products. 


\title{
Plant Growth Regulators' Effect on Growth of Mixed Cool-Season Grass Stands at Fort Drum
}

\author{
ANTONIO J. PALAZZO, PAUL ZANG, ROBERT W. DUELL, \\ TIMOTHY J. CARY AND SUSAN E. HARDY
}

\section{INTRODUCTION}

Turfgrasses that provide a suitable vegetative cover for parade grounds, roadsides, and housing areas are widely used in cantonment areas at military facilities. In the training areas, grasses are a cost-effective means of controlling erosion on the gunnery ranges. In all these areas, the grasses must be mowed to maintain the required visibility or appearance of a mowed turf. Fort Drum is currently mowing approximately 2,025 ha $(5,000$ acres $)$ of turf in the cantonment area and several hundred acres at the gunnery ranges. Grasses are usually mown to reduce leaf height or to remove seedheads.

The cost of mowing these lands is expensive in labor and equipment and may add up to several hundred dollars per acre annually. Innovative techniques are required to reduce mowing costs, control erosion, and maintain the aesthetics of turf areas, allowing the labor and money saved to be used for special projects or other maintenance functions. Plant growth regulators (PGRs) have the potential to reduce mowing costs.

The PGR "Embark" contains mefluidide $\{\mathrm{N}-$ [2,4-dimethyl-5-[[(trifluoromethyl)-sulfonyl] amino] phenyl] acetamide\}, which was commercially introduced in 1978 as a seedhead and foliar suppressant for use in rough turf areas (Elkins 1983, Johnston and Faulkner 1985). Watschke et al. (1992) provided an excellent review on methods of application and the functions of mefluidide within plants. Field and Witford (1982) reported that applications of mefluidide should be limited to green and actively growing grass. For leaf growth regulation, mowing the sward 4 to 5 days before or after the application will provide a sustained mowed appearance. The timing of mefluidide applications is more critical for opti- mal seedhead control; it should be applied at least 14 days before seedhead emergence. Turf injury is a factor to be considered when using PGRs. Some stand density losses have been observed (Wakefield and Fales 1977) and visual injury is more pronounced when the grass is environmentally stressed (Duell et al. 1977), but these factors are less important in low-maintenance turf situations. The effectiveness of PGRs in reducing turfgrass growth has been reported to be substantially reduced during years of low rainfall (Reynolds et al. 1993).

Mefluidide retards plant growth through the inhibition of cell division and meristematic activity in the responsive plant areas where the compound is absorbed. Mefluidide is absorbed by the leaf and exhibits little translocation to other leaf organs, roots, and lateral growth meristems (Field and Witford 1982, WSSA 1983). Penetration of leaf tissue occurs most readily at basal leaf sheaths and leaf axils, where cell division and elongation occur, causing reduced sheath extension and canopy height. Uptake is complete in 4 to 6 hours after application (Tautvydas 1983). Mefluidide also causes uncontrolled cell division in reproductive apices, distorting stem extension and impairing seedhead development (Field and Witford 1982). Because of limited movement within the plant, uniform spray coverage and distribution is essential (Watschke et al. 1992).

The PGR "Event" contains imidazolinone [5ethyl-2- (4-isopropyl-4-methyl-5-oxo-2-imidazolin-2-yl) nictotinic acid]. This compound has an extremely high margin of safety (Watschke et al. 1992). It has post-emergence herbicide activity on many annual and perennial grasses. Watschke et al. (1992), in their review of PGRs, reported that some studies with this PGR have shown the compound to suppress foliar growth and seedhead 
production of cool-season species, while another study with the similar species did not find any significant control of cool-season grass growth.

The overall objective of this research is to provide statistically clear and scientifically sound data on the effectiveness of two plant growth regulators (PGRs) to reduce the development of seedheads and inhibit the vertical growth (plant height) of mixed turf swards at multiple sites.

\section{STUDY AREA}

Four roadside turfgrass sites, a gunnery range and an earth-covered magazine (ECM) site were subjected to various combinations of applications of two plant growth regulators (PGRs) in 1994 and 1995. The four roadside sites were located along Hospital Lane, Memorial Drive and 5th Armored Division Drive (two sites). The Memorial Drive and 5th Armored Division Drive sites were seeded about eight years ago, and are mowed biweekly during the growing season. The other sites (on Hospital Lane and on the gunnery range) are mowed less frequently (approximately monthly).

Prior to treatment, the treated sites had the following characteristics and botanical compositions:

- Memorial Avenue: Level roadside area containing a mixed botanical composition dominated by tall fescue (Festuca arundinacea Shreb.)

- 5th Armored Division Drive: Sloping roadside area containing a mixed botanical composition dominated by tall fescue and Kentucky bluegrass (Poa pratensis L.) and some fine fescue (Festuca sp.) and infested with vetch (Vicia sp.) and knapweed (Centaurea maculosa L.).

- Hospital Lane: Level area consisting of fine fescues and contaminated by knapweed.

- Gunnery Range: Sloping area of low maintenance turf consisting primarily of Kentucky bluegrass.

- Earth-covered magazine: Dominated by quackgrass (Agropyron repens L.).

\section{MATERIALS AND METHODS}

Each site was laid out to receive seven treatments, which included five treatments with the PGR Embark, containing mefluidide, and Event, containing imidazolinone. Each PGR was applied individually at the manufacturer's recommended rate and at one-third the recommended rates, and the two PGRs were applied in combination at one-third the recommended rate. Each site included two check plots: one mowed biweekly and one unmowed. The minimum research plot size was $1 \times 9 \mathrm{~m}(4 \times 30 \mathrm{ft})$, which provided a clear visual assessment on the effectiveness of each treatment. The plots were initially outlined in April by applying Roundup herbicide to "brown" 10 -cm (4-in.) lines approximately one week before the experimental treatments.

The recommended and low rates for Embark (mefluidide) were 2.3 and $0.8 \mathrm{~L} /$ ha (2 and 0.67 pints/acre); for Event (imidazolinone) they were 438 and $146 \mathrm{~mL} / \mathrm{ha}$ (6 and $2 \mathrm{oz} / \mathrm{acre}$ ), respectively. Due to a miscalculation, the Hospital Lane plots received 1.5 times the rates applied to the other plots in 1994. Prior to spraying we added $0.25 \%(\mathrm{~V} / \mathrm{V})$ nonionic detergent to the spray-tank mixture to assist PGR absorption. The spraying volume of the detergent was $39.36 \mathrm{~L} / \mathrm{ha}$ (4.2 gal./ acre).

The PGRs were applied with a $\mathrm{CO}_{2}$-powered sprayer (set at $34 \mathrm{lb} /$ in. $^{2}$ or $235 \mathrm{kPa}$ ) with the single wide-angle even-edge Tee Jet $8006 \mathrm{E}$ nozzle calibrated to apply $200 \mathrm{~L} / \mathrm{ha}$ (21.36 gal./acre) in a 1 -m width from a $50-\mathrm{cm}$ height. The contents of a 2-L soft-drink bottle evenly covered 1/100-ha area between the burned-in strips.

The roadside test areas were sprayed in early spring on 10 May 1994 and on 2 May 1995. In 1995, the same treatments were applied again over the 1994 roadside plots as well as on adjacent untreated areas.

In 1994, the test sites were measured for PGR effect on plant growth. On 9 June, the percentage control of grass seedheads and foliage height were recorded. Seedhead production was determined by counting over a $0.5-\mathrm{m}^{2}\left(1.5-\mathrm{ft}^{2}\right)$ area. Mean foliar height was determined by readings of multiple drops of a $0.3-\mathrm{m}^{2}\left(1-\mathrm{ft}^{2}\right)$ slotted cardboard. The cardboard was dropped down a meter stick and allowed to settle on the grass foliage; the foliar height was the measured distance between the cardboard and the soil surface. In 17 June 1995, counts were made using these same techniques at all test sites for seedhead number and plant height.

Also in 1995, the growth rate of grasses was determined in a separate area where the dry weight of the grass was recorded by biweekly harvesting. Half the area at this site was sprayed 
biweekly with mefluidide at the recommended rate and the other half was untreated. The turf in this area consisted of mixed stands of tall and fine fescue. Dry weights of the grasses harvested biweekly from this area were recorded after oven drying at $70^{\circ} \mathrm{C}$ for 48 hours.

Analyses of variance of the data were performed using CoStat (1990) version 4.20 (CoHort Software). Least significant differences (LSD) were calculated at $5 \%$.

\section{RESULTS}

\section{Experiments}

Data on the control of seedheads are shown in Table 1. Tall fescue seedheads, which dominated the unmowed plots of 5th Armored Division Drive, were well controlled by PGR treatments except for the low rate of imidazolinone (onethird of that recommended). Seedheads at Hospital Lane, dominated by the earlier-flowering fine fescue, were well controlled only by the recommended rate of mefluidide and by mowing. At

Table 1. Percentage seedhead control on 9 June 1994 at the 5th Armored Division Drive I, Hospital Lane and earthcovered magazine sites.

\begin{tabular}{lccr}
\multicolumn{1}{c}{ Treatments } & $\begin{array}{c}\text { 5th Armored } \\
\text { Div. Drive I }\end{array}$ & Hospital Lane & ECM \\
\hline 1. Mefluidide, $2.3 \mathrm{~L} / \mathrm{ha}$ & 96.0 & 97.7 & 94.3 \\
2. Mefluidide, 0.67 L/ha & 95.3 & 6.0 & 95.0 \\
3. Imidazolinone, $438 \mathrm{~mL} / \mathrm{ha}$ & 93.3 & 56.7 & 83.3 \\
4. Imidazolinone, $136 \mathrm{~mL} / \mathrm{ha}$ & 38.3 & 21.7 & 7.0 \\
5. Treatment 2 + 4 & 98.7 & 53.3 & 93.3 \\
6. Mowed check & 99.7 & 100.0 & 99.0 \\
7. Unmowed check & 1.0 & 21.7 & 0.3 \\
\hline
\end{tabular}

Least significant

difference at 0.05 level

$\begin{array}{llll}\text { of probability } & 27.4 & 27.8 & 20.8\end{array}$

Table 2. Foliar height on 10 June 1994 at three sites.

\begin{tabular}{lccc}
\multicolumn{1}{c}{ Treatments } & $\begin{array}{c}\text { 5th Armored } \\
\text { Div. Drive II }\end{array}$ & $\begin{array}{c}\text { Memorial } \\
\text { Drive }\end{array}$ & $\begin{array}{c}\text { Hospital } \\
\text { Lane }\end{array}$ \\
\hline 1. Mefluidide, 2.3 L/ha & 14.7 & 10.6 & 10.0 \\
2. Mefluidide, 0.67 L/ha & 21.0 & 14.0 & 12.0 \\
3. Imidazolinone, $438 \mathrm{~mL} / \mathrm{ha}$ & 17.7 & 16.7 & 12.7 \\
4. Imidazolinone, $136 \mathrm{~mL} / \mathrm{ha}$ & 26.0 & 20.7 & 15.7 \\
5. Treatment 2 + 4 & 16.0 & 14.0 & 14.3 \\
6. Mowed check & 5.0 & 5.0 & 5.0 \\
7. Unmowed check & 33.0 & 22.3 & 18.3 \\
\hline
\end{tabular}

Least significant difference at 0.05 level of probability the ECM, where quackgrass dominated the vegetative cover, mefluidide controlled seedheads better than imidazolinone and its effect was similar to the mowed control. The combination of the two PGRs also controlled seedhead development at the ECM site. At the 5th Armored Division sites, broadleaf weeds (knapweed) were unaffected by the PGR treatments.

Mefluidide at the recommended rate provided the best control of foliar height (Table 2). The differences were greater for the Memorial Drive sites than for the fine-fescue dominated Hospital Lane location.

The effect of PGR treatment on turf color was highly variable (Table 3 ). Color did improve with time over the two rating dates of 9 June and 11 August 1994.

\section{Experiments}

The plant height data collected for each location and PGR treatment are shown in Appendix A. Since the differences between treatments were similar at most sites, we used the means of the individual treatments for each harvest date at each site (Table 4). No differences were noted after the first rating date (17 May 1995), which was about 15 days after the treatments were applied. This is probably related to the early effectiveness of all PGR treatments. Differences between treatments became apparent from the next rating date (30 May 1995) to the end of the rating period (25 July 1995). The results show that mefluidide at the recommended rate was statistically similar to the mowed control in reducing plant height. The next best treatments were mefluidide at the low rate and the mefluidide/imidazolinone combination. The imidazolinone treatment at both rates studied did not control plant height as well as those treatments that included mefluidide.

Significant differences for plant heights were also found between locations regardless of PGR treatment (Table 5). The differences in locations are probably due to the type of grasses growing at each location. The Hospital Lane site has the shorter growing fine fescues and the other sites contain tall fescue and Kentucky bluegrasses along with the fine fescues. 
Table 3. Visual estimates of green color (\%) on 9 June and 11 August 1994 at three locations.

\begin{tabular}{|c|c|c|c|c|c|c|}
\hline \multirow[t]{2}{*}{ Treatments } & \multicolumn{2}{|c|}{$\begin{array}{l}\text { 5th Armored } \\
\text { Div. Drive I }\end{array}$} & \multicolumn{2}{|c|}{$\begin{array}{l}\text { 5th Armored } \\
\text { Div. Drive II }\end{array}$} & \multicolumn{2}{|c|}{ Memorial Drive } \\
\hline & 9 June & 11 June & 9 June & 11 June & 9 June & 11 June \\
\hline 1. Mefluidide, $2.3 \mathrm{~L} / \mathrm{ha}$ & 75.0 & 98.3 & 91.7 & 96.0 & - & 100.0 \\
\hline 2. Mefluidide, $0.67 \mathrm{~L} /$ ha & 99.3 & 96.3 & 99.3 & 92.0 & - & 92.0 \\
\hline 3. Imidazolinone, $438 \mathrm{~mL} / \mathrm{ha}$ & 71.7 & 96.7 & 81.7 & 88.7 & - & 92.0 \\
\hline 4. Imidazolinone, $136 \mathrm{~mL} / \mathrm{ha}$ & 93.0 & 93.3 & 99.3 & 87.3 & - & 88.0 \\
\hline 5. Treatment $2+4$ & 78.3 & 95.7 & 91.7 & 96.3 & - & 91.7 \\
\hline 6. Mowed check & 75.0 & 95.0 & 81.7 & 97.3 & - & 95.3 \\
\hline 7. Unmowed check & 99.3 & 86.7 & 58.3 & 85.0 & - & 88.3 \\
\hline
\end{tabular}

Least significant

difference at 0.05 level

$\begin{array}{lllllll}\text { of probability } & 12.0 & 4.1 & 18.8 & 4.6 & - & 22.8\end{array}$

Table 4. Plant heights $(\mathrm{cm})$ as influenced by various treatments in 1995.

\begin{tabular}{lcccccc}
\multicolumn{1}{c}{ Treatments } & 17 May & 30 May & 14 June & 27 June & 11 July & 25 July \\
\hline 1. Mefluidide, 2.3 L/ha & 8.8 & 7.8 & 14.0 & 13.9 & 13.1 & 14.0 \\
2. Mefluidide, 0.67 L/ha & 9.5 & 10.2 & 17.6 & 18.9 & 21.5 & 25.1 \\
3. Imidazolinone, 438 mL/ha & 9.4 & 9.9 & 19.3 & 25.7 & 29.7 & 28.8 \\
4. Imidazolinone, 136 mL/ha & 8.7 & 10.4 & 21.0 & 27.1 & 29.7 & 34.1 \\
5. Treatment 2 + 4 & 9.0 & 9.4 & 17.7 & 17.1 & 16.8 & 19.5 \\
6. Mowed check & 11.3 & 9.1 & 12.7 & 12.2 & 12.1 & 14.9 \\
7. Unmowed check & 11.5 & 13.1 & 25.4 & 27.7 & 32.6 & 32.4 \\
\hline
\end{tabular}

Least significant difference at 0.05 level $\begin{array}{lllllll}\text { of probability } & 1.2 & 1.4 & 1.4 & 6.1 & 7.2 & 2.7\end{array}$

Table 5. Plant heights $(\mathrm{cm})$ as influenced by various experimental locations in 1995.

\begin{tabular}{llrrrrrr}
\multicolumn{1}{c}{ Location } & & 17 May & 30 May & 14 June & 27 June & 11 July & 25 July \\
\hline 5th Armored Div. Drive I & Single* & 10.1 & 8.9 & 19.2 & 23.5 & 30.0 & 31.7 \\
5th Armored Div. Drive I & Reapply & 9.5 & 8.2 & 16.5 & 20.1 & 24.4 & 27.0 \\
5th Armored Div. Drive II & Single & 11.0 & 11.7 & 21.4 & 22.2 & 23.4 & 26.8 \\
5th Armored Div. Drive II & Reapply & 11.8 & 12.5 & 23.2 & 26.3 & 26.1 & 28.4 \\
Hospital Lane Single & & 8.3 & 8.3 & 13.6 & 13.8 & 12.8 & 12.3 \\
Hospital Lane reapply & & 7.9 & 10.4 & 15.6 & 16.3 & 16.4 & 18.5 \\
\hline LSD at 5\% & 1.2 & 1.2 & 1.9 & 3.8 & 5.5 & 6.4 \\
* Single = PGR applied in 1995 only & & & & & & \\
$\quad$ 'Reapply = PGR applied in 1994 and 1995 & & & & & &
\end{tabular}

No differences in plant heights were observed between the initial and the reapplication treatments at the two 5th Armored Division Drive locations (Table 5). This indicates that the reapplication of the PGR was consistently as beneficial the second year.

Seedhead control is important since seedheads give the appearance that the turf requires mowing. Significant (probability less than 5\%) differ- ences in seedhead counts were noted for the type of PGR used and the location of the test, but no differences were found between the three rating dates. Table 6 shows the number of seedheads on 27 June in plots where the PGR was initially applied in 1994 and then reapplied in 1995. Mefluidide at the recommended rate provided the best control of seedhead development, with none of the treatments producing more than 2 
Table 6. Seedhead counts taken at each location on 27 June 1995.

\begin{tabular}{|c|c|c|c|c|c|c|c|c|}
\hline \multirow[b]{2}{*}{ Treatments } & \multicolumn{2}{|c|}{ Hospital Lane $\ddagger$} & \multicolumn{2}{|c|}{$\begin{array}{c}\text { 5th Armored Div. } \\
\text { Drive I } \\
\end{array}$} & \multicolumn{2}{|c|}{$\begin{array}{l}\text { 5th Armored Div. } \\
\text { Drive II }\end{array}$} & \multicolumn{2}{|c|}{ Memorial Drive } \\
\hline & Single* & Reapply ${ }^{\dagger}$ & Single & Reapply & Single & Reapply & Single & Single \\
\hline 1. Mefluidide, $2.3 \mathrm{~L} / \mathrm{ha}$ & 2.9 & 0.8 & 1.4 & 1.3 & 0.9 & 2.2 & 1.6 & 1.6 \\
\hline 2. Mefluidide, $0.67 \mathrm{~L} / \mathrm{ha}$ & 23.2 & 6.8 & 4.7 & 7.4 & 8.6 & 10.9 & 11.8 & 10.5 \\
\hline 3. Imidazolinone, $438 \mathrm{~mL} / \mathrm{ha}$ & 29.2 & 18.3 & 9.0 & 8.4 & 14.3 & 12.2 & 13.1 & 14.9 \\
\hline 4. Imidazolinone, $136 \mathrm{~mL} / \mathrm{ha}$ & 39.6 & 21.8 & 10.4 & 7.0 & 16.7 & 11.1 & 14.4 & 17.3 \\
\hline 5. Treatment $2+4$ & 18.6 & 8.3 & 4.6 & 5.4 & 5.4 & 5.8 & 14.7 & 9.0 \\
\hline 6. Mowed check & 0.1 & 0.0 & 0.0 & 0.0 & 0.0 & 0.0 & 0.0 & 0.0 \\
\hline 7. Unmowed check & 48.2 & 18.8 & 12.7 & 8.7 & 22.0 & 10.1 & 19.4 & 20.0 \\
\hline LSD at $5 \%$ & 13.2 & 4.8 & 4.9 & 2.7 & 4.1 & 6.3 & 10.9 & \\
\hline
\end{tabular}

* Single $=$ PGR applied in 1995 only

${ }^{+}$Reapply = PGR applied in 1994 and 1995

$\ddagger$ Hospital Lane received 1.5 times the recommended rate in 1994

seedheads $/ \mathrm{m}^{2}$ at any of the locations. The number of seedheads produced by the unmowed check varied widely and was probably dependent on soil conditions at that location and the type of turf growing at the site. Mefluidide applied in combination with imidazolinone and at the lower rate provided the next best control of seedhead devel-

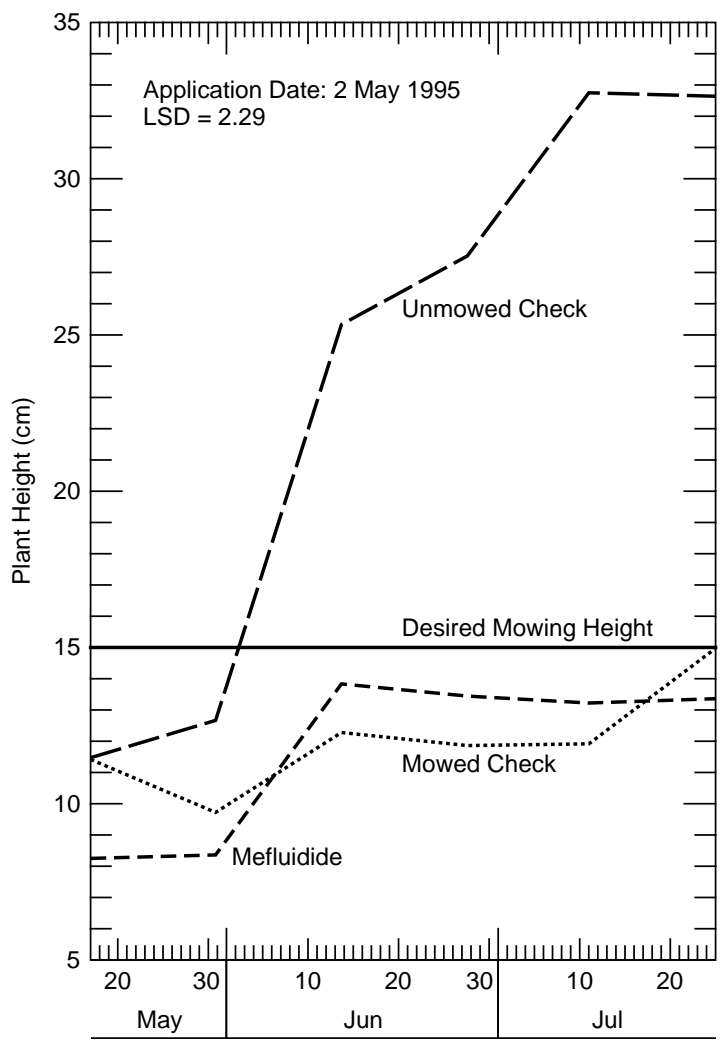

Figure 1. Effect of a plant growth regulator (PGR) on roadside vegetation maintenance (mefluidide applied at $2.3 \mathrm{~L} / \mathrm{ha}$ ). opment; these treatments provided about $50 \%$ decrease in seedhead development over the unmowed check. Imidazolinone provided only an average of 13 and $25 \%$ control of seedhead development for the low and recommended rates of application.

Plant height data recorded biweekly from PGRtreated and untreated plots at the six roadside locations are shown in Figure 1. The unmowed control produced consistently taller plants than the mowed control. The greatest differences between dates occurred between 30 May and 14 June 1995, where there was about a 100\% increase in height. The PGR treatment was mefluidide at the recommended rate and the mean height of treated plants was never greater than $15 \mathrm{~cm}(6$ in.). Increases in plant height did not correlate to those recorded for plant weight.

In the separate area adjacent to 5th Armored Division Drive, plant biomass production and plant heights were recorded biweekly from the mefluidide-treated and untreated mixed turfgrass stands. Significant differences in plant biomass were found for harvest date, PGR treatment, and their interactions. Biweekly increases in plant biomass were between 40 and $61 \%$ for the untreated grasses and only 9 and $22 \%$ for the treated plots. The yields on the final harvest (2 June 1995) was $100 \%$ greater in the control as compared to the treated grasses (Fig. 2).

\section{DISCUSSION AND CONCLUSIONS}

Plant heights and appearance of seedheads are usually the most identifiable indicators for determining when mowing should occur. The need for 


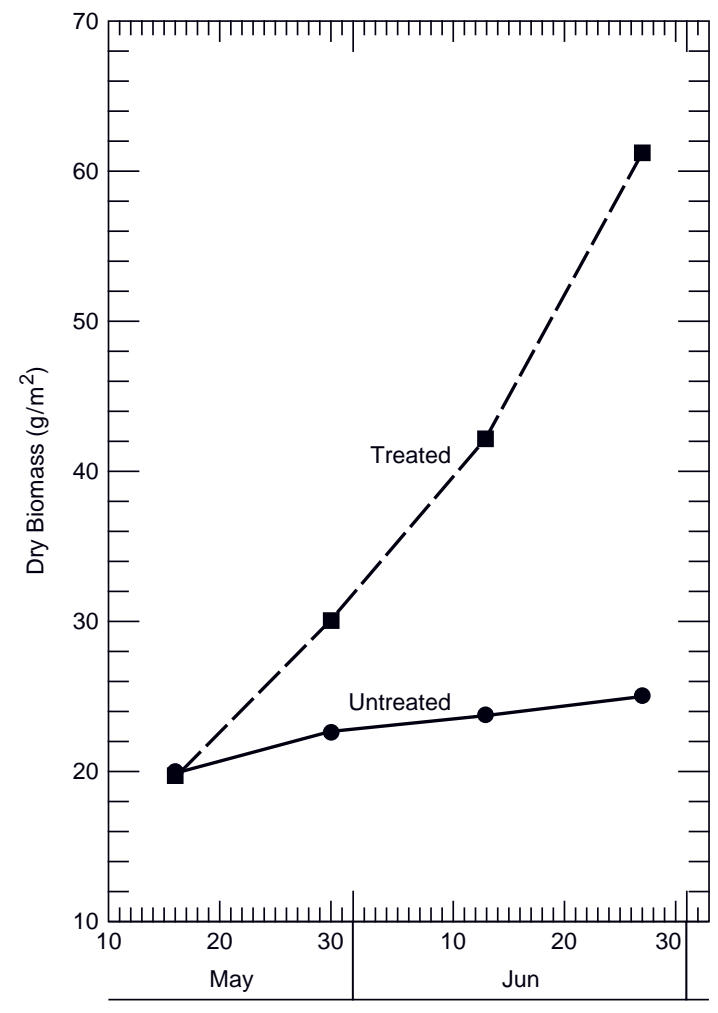

Figure 2. Plant yields recorded biweekly from PGR treated and untreated mixed turfgrass stands.

mowing is a very subjective decision. For the purposes of this study, we have assumed that when the turf reaches a height of $12.5 \mathrm{~cm}$ (5 in.), it should be mowed.

Mefluidide applied at the recommended rate of $2.3 \mathrm{~L} /$ ha provided the best control of plant height and seedhead development in 1995 (Fig. 1). Mefluidide applied at the low rate of $0.8 \mathrm{~L} / \mathrm{ha}$ provided some control, but not as much as the 2.3-L/ha rate. Most sites seemed to have the same general trends of differences in growth control between treatments. Reapplication of the same PGR treatments the following season produced similar results in growth and seedhead retardation. Rapid increases in plant height were not correlated with that for plant weight within the control treatments or under normal growing conditions. Therefore, the timing of PGR applications is critical to sufficiently inhibit the various growth spurts. The effect of PGR application on turf color was highly variable, but the color did improve after about two months.

The 1994 results showed that certain factors, such as early maturing quackgrass, the presence of broadleaf weeds, and the effects of a cool mi- croclimate in a fine-fescue-dominated area, will have an effect on PGR performance, and the growth inhibiting effect of applying a PGR will not be consistent over all turf areas. This inconsistency may necessitate additional mowing during the spring season. Although PGRs did not work uniformly over all areas, the mefluidide treatment at the recommended rate was consistent enough between test locations covering many turf species and microclimates to move it from the experimental to the demonstration stage of trial.

Control of broadleaf weeds will be necessary since the PGR is not effective in reducing their growth rate. Future applications of mefluidide should include a broadleaf weed herbicide. Recommendations for future trials or practices should also include mowing the site 4 to 5 days before and after application of the PGR to obtain a uniform turf stand in terms of height. The PGR should be applied in early May and the chemical should be effective for a period of 4 to 6 weeks.

\section{LITERATURE CITED}

CoStat (1988) Users Manual. Berkeley, California: CoHort Software.

Duell, R.W., R.M. Schmitt and S.W. Cosky (1977) Growth retardant effects on grasses for roadsides. In Proceedings of the 3rd International Turfgrass Research Conference (J.B. Feard, Ed.), Munich, Germany. 11-13 July. Madison, Wisconsin: International Turfgrass Society, ASA-CSSA-SSSA, p. 311-323.

Elkins, D.M. (1983) Growth regulating chemicals for turf and other grasses. In Plant Growth Regulating Chemicals (L.G. Nickel, Ed.), Vol. II. Boca Raton, Florida: CRC Press.

Field, R.S. and A.R. Witford (1982) Effect of simulated mowing on the translocation of mefluidide in perennial ryegrass (Lolium perenne L.) Weed Research, 22: 177-181.

Johnston, D.T. and J.S. Faulkner (1985) The effects of growth retardants on swards of normal and dwarf cultivars of red fescue. Journal of Sports Turf Research Institute, 61: 59-64.

Reynolds, J.H., W.A. Krueger and C.L. Waller (1993) Plant growth regulator effects on growth and forage quality of tall fescue. Agronomy Journal, 85: 545-548.

Tautvydas, K.G. (1983) Synergistic growth retardation of grasses with mefluidide/PGR combinations. p. 51-56. In Proceedings of the 10th Annual PGRSA Meeting.

Watschke, T.L., Prinster, and J.M. Breuninger 
(1992) Plant growth regulators and turfgrass management. In Turfgrass (D.V. Waddington, Ed.). Madison, Wisconsin: ASA-CSSA-SSSA.

Wakefield, R.C. and S.L. Fales (1977) Effects of growth retardants on the shoot and root growth of roadside turfgrasses. In Proceedings of the $3 r d$
International Turfgrass Research Conference (J.B. Feard, Ed.), Munich, Germany. 11-13 July. Madison, Wisconsin: International Turfgrass Society, ASA-CSSA-SSSA, p. 303-309.

WSSA (1983) Herbicide Handbook. Champaign, Illinois: Weed Science Society of America. 


\section{APPENDIX A: PLANT HEIGHT DATA (CM) RECORDED FROM INDIVIDUAL TREATMENTS AT VARIOUS SITES IN 1995}

\begin{tabular}{|c|c|c|c|c|c|c|}
\hline \multirow{2}{*}{ Treatments } & \multicolumn{2}{|c|}{ Hospital Lane* } & \multicolumn{2}{|c|}{$\begin{array}{c}\text { 5th Armored Division } \\
\text { Drive I }\end{array}$} & \multicolumn{2}{|c|}{$\begin{array}{c}\text { 5th Armored Division } \\
\text { Drive II }\end{array}$} \\
\hline & Single $^{+}$ & Reapply** & Single & Reapply & Single & Reapply \\
\hline \multicolumn{7}{|l|}{17 May 1995} \\
\hline 1. Mefluidide, $2.3 \mathrm{~L} / \mathrm{ha}$ & 7.0 & 8.3 & 9.2 & 8.2 & 9.7 & 10.2 \\
\hline 2. Mefluidide, $0.67 \mathrm{~L} / \mathrm{ha}$ & 8.1 & 7.7 & 8.8 & 10.2 & 11.3 & 11.2 \\
\hline 3. Imidazolinone, $438 \mathrm{~mL} / \mathrm{ha}$ & 8.3 & 8.8 & 8.7 & 8.9 & 11.1 & 10.6 \\
\hline 4. Imidazolinone, $136 \mathrm{~mL} / \mathrm{ha}$ & 7.0 & 7.6 & 8.2 & 9.8 & 11.0 & 9.7 \\
\hline 5. Treatment $2+4$ & 7.5 & 8.8 & 8.4 & 9.0 & 11.1 & 10.5 \\
\hline 6. Mowed check & 7.8 & 8.5 & 12.5 & 13.7 & 13.3 & 12.3 \\
\hline 7. Unmowed check & 9.3 & 8.2 & 10.7 & 13.0 & 15.2 & 12.6 \\
\hline \multicolumn{7}{|l|}{$\mathrm{LSD}$ at $5 \%=3.13$} \\
\hline \multicolumn{7}{|l|}{30 May 1995} \\
\hline 1. Mefluidide, $2.3 \mathrm{~L} / \mathrm{ha}$ & 8.4 & 6.7 & 7.6 & 7.9 & 7.7 & 8.7 \\
\hline 2. Mefluidide, $0.67 \mathrm{~L} / \mathrm{ha}$ & 11.3 & 8.1 & 8.5 & 9.9 & 12.7 & 10.6 \\
\hline 3. Imidazolinone, $438 \mathrm{~mL} / \mathrm{ha}$ & 10.1 & 9.7 & 6.8 & 9.9 & 12.2 & 10.7 \\
\hline 4. Imidazolinone, $136 \mathrm{~mL} / \mathrm{ha}$ & 10.2 & 8.2 & 9.6 & 9.1 & 14.3 & 11.2 \\
\hline 5. Treatment $2+4$ & 9.5 & 7.6 & 8.8 & 8.4 & 11.2 & 10.7 \\
\hline 6. Mowed check & 10.1 & 8.8 & 6.3 & 7.7 & 10.1 & 11.6 \\
\hline 7. Unmowed check & 12.9 & 9.3 & 9.4 & 9.2 & 19.6 & 18.1 \\
\hline $\mathrm{LSD}$ at $5 \%=3.17$ & & & & & & \\
\hline \multicolumn{7}{|l|}{14 June 1995} \\
\hline 1. Mefluidide, $2.3 \mathrm{~L} / \mathrm{ha}$ & 10.8 & 10.8 & 13.0 & 15.3 & 18.7 & 15.2 \\
\hline 2. Mefluidide, $0.67 \mathrm{~L} / \mathrm{ha}$ & 15.3 & 12.7 & 14.8 & 15.7 & 28.2 & 18.8 \\
\hline 3. Imidazolinone, $438 \mathrm{~mL} / \mathrm{ha}$ & 16.2 & 14.5 & 18.8 & 19.0 & 24.2 & 23.0 \\
\hline 4. Imidazolinone, $136 \mathrm{~mL} / \mathrm{ha}$ & 17.5 & 16.3 & 17.0 & 21.0 & 26.8 & 27.5 \\
\hline 5. Treatment $2+4$ & 16.3 & 14.3 & 17.2 & 18.3 & 21.7 & 18.3 \\
\hline 6. Mowed check & 11.7 & 11.0 & 11.8 & 14.3 & 14.0 & 13.5 \\
\hline 7. Unmowed check & 21.2 & 15.3 & 22.7 & 30.8 & 28.8 & 33.7 \\
\hline LSD at $5 \%=5.04$ & & & & & & \\
\hline \multicolumn{7}{|l|}{ 27 June 1995} \\
\hline 1. Mefluidide, $2.3 \mathrm{~L} / \mathrm{ha}$ & 9.1 & 9.2 & 17.2 & 14.8 & 18.5 & 14.7 \\
\hline 2. Mefluidide, $0.67 \mathrm{~L} / \mathrm{ha}$ & 17.9 & 13.5 & 13.8 & 19.7 & 29.0 & 18.5 \\
\hline 3. Imidazolinone, $438 \mathrm{~mL} / \mathrm{ha}$ & 17.7 & 15.3 & 37.2 & 25.3 & 29.0 & 29.8 \\
\hline 4. Imidazolinone, $136 \mathrm{~mL} / \mathrm{ha}$ & 19.3 & 19.8 & 18.8 & 29.8 & 42.0 & 32.5 \\
\hline 5. Treatment $2+4$ & 17.3 & 12.5 & 14.8 & 19.8 & 19.2 & 19.0 \\
\hline 6. Mowed check & 9.3 & 9.4 & 18.7 & 12.3 & 12.0 & 11.7 \\
\hline 7. Unmowed check & 23.2 & 16.8 & 19.9 & 42.7 & 34.5 & 29.3 \\
\hline LSD at $5 \%=14.152$ & & & & & & \\
\hline \multicolumn{7}{|l|}{11 July 1995} \\
\hline 1. Mefluidide, $2.3 \mathrm{~L} / \mathrm{ha}$ & 7.0 & 7.5 & 19.6 & 13.0 & 17.0 & 14.3 \\
\hline 2. Mefluidide, $0.67 \mathrm{~L} / \mathrm{ha}$ & 20.4 & 12.3 & 19.5 & 23.1 & 29.0 & 24.7 \\
\hline 3. Imidazolinone, $438 \mathrm{~mL} / \mathrm{ha}$ & 20.7 & 14.2 & 48.8 & 36.0 & 24.7 & 33.5 \\
\hline 4. Imidazolinone, $136 \mathrm{~mL} / \mathrm{ha}$ & 17.1 & 17.8 & 24.2 & 43.7 & 45.2 & 30.0 \\
\hline 5. Treatment $2+4$ & 17.2 & 11.5 & 14.7 & 23.5 & 17.2 & 16.8 \\
\hline 6. Mowed check & 7.4 & 7.5 & 27.7 & 9.7 & 10.0 & 10.2 \\
\hline 7. Unmowed check & 25.2 & 18.8 & 16.2 & 61.2 & 39.7 & 34.5 \\
\hline
\end{tabular}


5th Armored Division 5 th Armored Division

Treatments

Hospital Lane*

Drive I

25 July 1995

1. Mefluidide, $2.3 \mathrm{~L} / \mathrm{ha}$ Single $^{+}$Reapply $^{* *}$ Single Reapply

Drive II

2. Mefluidide, $0.67 \mathrm{~L} / \mathrm{ha}$

9.6

24.0

8.3

17.5

11.2

34.3

38.7

23.3

12.2

38.2

3. Imidazolinone, $438 \mathrm{~mL} / \mathrm{ha}$

18.9

16.2

$16.4 \quad 12.8$

22.7

7.3

7.9

20.3

30.0

17.0

17.6

12.2
16.8
38.2
54.5
33.8
8.7
57.8

16.8

31.7

33.5

42.8

14.7

21.5

37.8

Reapply

LSD at $5 \%=17.00$

* Hospital Lane received 1.5 times the recommended rate in 1994

${ }^{\dagger}$ Single $=$ PGR applied in 1995 only

** Reapply = PGR applied in 1994 and 1995 


\begin{tabular}{|l|l|l}
\hline 1. AGENCY USE ONLY (Leave blank) & $\begin{array}{c}\text { 2. REPORT DATE } \\
\text { September } 1996\end{array}$ & 3. REPORT TYPE AND DATES COVERED
\end{tabular}

Plant Growth Regulators' Effect on Growth of Mixed Cool-Season Grass Stands at Fort Drum 6. AUTHORS

Antonio J. Palazzo, Paul Zang, Robert W. Duell, Timothy J. Cary and Susan E. Hardy

7. PERFORMING ORGANIZATION NAME(S) AND ADDRESS(ES)

U.S. Army Cold Regions Research and Engineering Laboratory

72 Lyme Road

Hanover, New Hampshire 03755-1290

8. PERFORMING ORGANIZATION REPORT NUMBER

9. SPONSORING/MONITORING AGENCY NAME(S) AND ADDRESS(ES)

Special Report 96-24

Environmental Division

85 First Street West

Fort Drum, New York 13062-5097
Headquarters

U.S. Army Forces Command

Fort McPherson, Georgia 30330-6000

11. SUPPLEMENTARY NOTES

For conversion of SI units to non-SI units of measurement consult ASTM Standard E380-93, Standard Practice for Use of the International System of Units, published by the American Society for Testing and Materials, 1916 Race St., Philadelphia, Pa. 19103.

12a. DISTRIBUTION/AVAILABILITY STATEMENT

12b. DISTRIBUTION CODE

Approved for public release; distribution is unlimited.

Available from NTIS, Springfield, Virginia 22161

13. ABSTRACT (Maximum 200 words)

Mowing is one of the more expensive operations in managing roadside and other low-maintenance turfgrass areas. The objective of this study was to evaluate the performance of two plant growth regulators (PGRs)mefluidide (Embark) and imidazolinone (Event) —in reducing the development of seedheads and inhibiting the vertical growth (plant height) of mixed turf swards at multiple sites over a two-year period. Mefluidide applied at the manufacturer's recommended rate $(2.3 \mathrm{~L} /$ ha or 2 pints/acre) provided the best general control of plant height and seedhead development compared to mefluidide at lower rates or imidazolinone at both recommended and lower rates or a combination of mefluidide and imidazolinone at lower rates. Within the control areas (no PGR), plant height did not correlate with plant weight. Therefore, the timing of treatments is critical since increases in plant height and weight occur at different times during the spring. At the early May application time, mefluidide applied at the recommended rate inhibited both plant height and weight. The effects of this treatment on plant growth were similar in most of the eight sites tested. However, PGR performance was affected by the presence of earlier maturing grasses in the sward, microclimatic factors, and broadleaf weeds. There was no difference in the effectiveness of the treatments when the materials were applied again during the following season. Despite some variation in its effect, the mefluidide treatment at the recommended rate was consistent enough among all test locations, turf species, and microclimates to recommend using this technique in the demonstration stage of the trial.

\begin{tabular}{|c|c|c|c|}
\hline \multirow{2}{*}{$\begin{array}{l}\text { 14. SUBJECT TERMS } \\
\text { Cold regions }\end{array}$} & \multirow[b]{2}{*}{ Plant growth regulators } & \multirow{2}{*}{ Turfgrasses } & $\begin{array}{c}\text { 15. NUMBER OF PAGES } \\
17\end{array}$ \\
\hline & & & 16. PRICE CODE \\
\hline UNCLASSIFIED & UNCLASSIFIED & UNCLASSIFIED & UL \\
\hline
\end{tabular}

